\title{
Commemoration / Memorial Days
}

\author{
By MiHaila Yordanova
}

"It's almost like the $7^{\text {th }}$ of November under Ben Ali (Bin 'Alī)," notes a young informant, describing the atmosphere on Bourguiba avenue on January 14, vividly recreated in the virtual pages of Nawaat. Music is blasting from loudspeakers, the Tunisian flag proudly displayed on a massive screen. Thousands of people are slowly making their way through the crowds gathered in the centre of the Tunisian capital [ $\nearrow$ Downtown/Centre-ville]. Parents are pushing strollers or holding the hands of their toddlers in the periphery of the scene, in an attempt to avoid the small island of greenery situated in the middle of the boulevard. Adolescents are navigating the sea of people, clutching boutique shopping bags in their hands. All the tables in the myriad of cafes and restaurants around the street are taken, no space to spare, yet some are optimistically gathering around the entrances, waiting for a spot to be freed. At the west end a stage is erected, accessorized with a screen and loudspeakers. It is the meeting point for the supporters of the Ennahdha (al-nahda) movement. "Al-shac $b$ yurìd al-nahda min jadìd" (The people want al-Nahda again), the chant is merging with the last accords of "Hīlā hìla ya mațar" ("Come down, oh rain," a revolutionary song strongly connected to the image of the singer and leftist activist Amel Hamrouni ('Amāl al-Hamrūnī), an outspoken critic of al-Nahda). At the opposite site of the street some of the members of the Union of Unemployed Graduates (UDC) are banging spoons against empty metal plates, an allusion to both the ongoing hunger strike protesting the current situation of the political opponents of Ben Ali and the economic situation in the country. "Do you know what they want?," asks one of the policemen protecting the ministry, addressing one of his colleagues, as they observe protesters speaking to their audience while balancing their weight half-way up a couple of tree trunks. The river of bodies is intersected by a tight current. The relatives of the martyrs of the Revolution are walking past determinedly, holding the pictures of their long-lost loved ones. "Shughl, hurriyya, karāma wațaniyya" ("Work, freedom, national dignity," one of the slogans of the revolution), shouts someone. In other parts of the boulevard various smaller and bigger associations, political parties and unions are raising their banners, in protest or support of one cause or another. It seems that everyone has something to say. After all, concludes the article, many of the people here do not want to celebrate "but to demonstrate in the name of the unachieved objectives of the Revolution," to attempt to break the "circle of marginalization and oblivion" [ $\nearrow$ Voice vs. Sillence].

"Celebrating what? The politicians who do nothing but business?" asks the popular cartoon cat Willis on Facebook, the caricature depicting the hero and a friend gathered around a cake with lit candles, angrily listing all the changes from the past five years in Tunisia. "The institutionalized corruption! The thousands of young people rotting in prison for smoking a joint! The continuing torture! The criminalization of homosexuality! The rising living costs!" "There is nothing to celebrate!" comes the conclusion, but at least there is beer. 
Dear friends, I wish you a happy fifth anniversary of the revolution. I am as disgusted as you are with the turn events took. We wonder how all the vibrant social energies have allowed this band of clowns to dominate the political scene. [ 7 Hope vs. Hell]

Thus opens a post published by the blogger _ Z on the anniversary of the Tunisian Revolution. The middle of the page-long article is occupied by a vivid image, depicting the Sousse conference (an event held by the ruling Nida Tunis just days after top cabinet posts are reassigned amidst criticism of the role of the president's son Hafedh Essebsi (Hāfiz alSibsī), which also includes a seven-minute speech by the leader of the rival Islamist part alNahda). Surrounded by a cheering, animal-like crowd, Beji Caid Essebsi (Bājī Qā̉id al-Sibsī) is performing fellatio on Rached Ghannouchi (Rāshid al-Ghannūshī). With his mouth full, he turns to his son Hafedh (Hāfiz), who is scribbling on the constitution and says: "Take a note of what is happening, my son!" The author comments: I know you will excuse the obscenity of this drawing. It is still very far from the vulgarity which contaminates the Tunisian political landscape, which has obviously betrayed the promises of the Revolution. In these sad times, I hope that this January 14 will return to the fundamentals of the revolution and will send a message of support to those who have lost their lives during the revolution, those who still suffer in their flesh and those unable to get out. Understand, my friends, the revolution was never Tunisian, nor was it carried out by the majority. It was a spirit. A breach of the mundane that suddenly opened in an ocean of ever-present bullshit. But it is in this breach that we continue to believe, sums up the article.

But not everybody remembers things like this. "That day was nightmarish," a girl recalls the eve of the $14^{\text {th }}$ January in an article published by the Huffington Post, "We were locked in at home with our family, waiting for the situation to stabilize." Another witness of the events adds: "I wasn't happy to see Ben Ali go. My mother spent the night crying over his departure. Things aren't much better now [ $\nearrow$ Past vs. Present]. Safety and security left along with him." There is an overwhelming feeling that everything has gone downhill since 2011 , unemployment is still present, prices are up, the tourists are gone [ $\nearrow$ Tourist Resorts]. "The revolution did not help me in any way," comment even those gathered to commemorate it.

Not that everyone agrees. The fifth anniversary of the revolution coincides with the release of the first feature-length movie by Layla Bouzid (Laylà Būzīd). "As I open my eyes" ('Alà hallat 'aynī / À peine j'ouvre les yeux) is set in 2010 and tells the story of Farah, a recently graduated strong-minded young woman who decides to concentrate on working with her band, rather than to study medicine, as her family suggests. The news is received particularly badly by the girl's overly-protective mother, Hayāt, who is determined to keep her safe at home. The political lyrics of the band, however, soon attract the attention of the police. Farah is taken into custody and her mother is left to navigate the complex political and social landscape of Tunis, in an attempt to find her. Eventually, the girl is returned to the family after enduring torture and sexual assault and sinks into depression, her previously rebellious spirit shattered to pieces, while her mother finds her previously lost desire to challenge the status quo. The film is a moving story of the bond between mother and daughter, of the power of love, but also of the ways authoritarian regimes end up awaking their people, while attempting to break them down. And to some it is more than that. "Like any post-totalitarian society, the Tunisian society is navigating around two pitfalls: amnesia and nostalgia, which are connected to each other," notes one reviewer. "It is the role of the

jais • 21 (2021) - Themed Section In2016: *45_*58 
artist to assist in this navigation, giving their society distant or near images which make them feel and reflect on what is happening. [The young protagonists] are emblematic of a generation which continues on its path. Their minds have begun to be free and now they need to free their bodies and those of their parents. A large building site, which engages all of society and not one particular social class" [ $\nearrow$ Past vs. Present].

January 23. Crowds gather at Cairo's police academy to mark Police Day and Youm 7

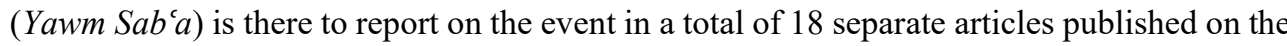
website the same day. Emotions are running high and the updates are pouring: "The ceremony begins," "Al-Sisi arrives" , "A child recites a poem, entitled "Martyr." With the end of the day approaching, however, more content-heavy articles appear. A summary of the top five moments of the day is published, as well as the full text of the speeches of the president and Magdi Abdel Ghaffar (Magdī 'Abd al-Ghaffār) both of which give a good idea of the tone and message of the event.

This is a day which evokes a feeling of pride and honour and willingness to make sacrifices not only in the members of the police department, but also in every Egyptian who belongs to this great homeland and who cherishes it above all [ $\nearrow$ The Honourable Citizen],

the interior minister exclaims. It is a day to reflect on the past and present but also to think of the future. The threat to Egypt's stability and security is not gone, terrorists are jeopardizing the country's very existence on a daily basis. Yet, with the help of the authorities, the army, the police and the nation, the country and the "pivotal role that it plays" shall be preserved [ $\nearrow$ Freedom vs. Constraint, $\lambda$ Security vs. Fear]. All in good time, of course, and all owing to the wisdom and support of al-Sisi himself.

With the mood being set, it is time for the headliner address. Talking on behalf of all Egyptians, President al-Sisi offers "eternal gratitude to the martyrs of the police force who have sacrificed their life and blood for Egypt and its people," promising that their act of heroism shall not be forgotten [ $\lambda$ Normality vs. Heroism]. The emotional climax of the speech, however, comes with the president's appeal to the nation. Gesturing towards the families of the fallen policemen standing behind him, he whispers: "We have paid a high price for the stability and security we currently live in. So, I ask all Egyptians, for the sake of the martyrs to protect their homeland." Thrown in the mix is also al-Sisi's strangely out-ofplace address to the people of Tunisia, warning them of the dangers of protesting and urging them to keep the country's interest in mind.

The ceremony takes place two days earlier to separate it from the fifth anniversary of the January Revolution, according to al-'Akhbār Lebanon. Despite that, January 25 also witnesses heavy coverage of Police Day celebrations, with many Egyptian satellite channels placing "the anniversary of the revolution in second place," argues the daily newspaper. It then goes on to describe the partial or altogether non-existent reporting of the event. Instead, claim the authors, the spotlight is on celebrating the fête of the police through emotional stories, such as the imaginary dialogue with a toddler who has lost his father in a terrorist attack, published by al-'Ahrām. "The media performance on that day reflected an implicit intention to fully restore Police Day" [ $\nearrow$ True vs. False], concludes the report, voicing fears that the legacy of the uprising is in danger.

jais 21 (2021) - Themed Section In2016:*45-*58 
But the celebrations of Police Day are not confined to the media realm. On the $25^{\text {th }}$ itself some supporters of the regime also take to the streets, their faces painted in the colours of the Egyptian flag, offering flowers, hugs and kisses to any policeman they meet. Two young men, however, have a very different gift in mind.

A short video, shot with a mobile phone, shows Ahmad Malik ('Ahmad Malik) and Shady Hussain (Šădī Husayn) roaming the streets around Tahrir square, sha $b \bar{\imath}$ music playing in the background [ $\nearrow$ Mobile Phones]. With smiles on their faces, the two young men hug and pose for a photo with the policemen guarding the square, handing them strangely-looking balloons bearing the message "From the youth of Egypt to the police on the $25^{\text {th }}$ January," written with a black marker. The youths wave the Egyptian flag and kiss the ground, in a seamless, albeit over-exaggerated, imitation of al-Sisi's supporters around them. "Long live Egypt" shouts one of them, barely able to contain his laughter. The public is let in on the joke. The clip starts in a shady apartment and pictures a group of amused young people inflating and decorating a bunch of condoms, the unusual balloons later so graciously received by the unwitting representatives of the police force. The video goes viral, not that much because of its mockery of the behaviour of the proud supporters of the President, but because it is also an attempt to reclaim the space which once served as a stage for the January Revolution and to defend its memory [ $\lambda$ Inferiority $v s$. Superiority, $\lambda$ Voice $v s$. Silence], using satire to achieve that $[\lambda$ Inferiority $=$ Superiority $($ Satire $)]$. Is it any wonder, then, that the regime seems so unappreciative of this particular type of humour, as their reaction to the events in question shows? [ 7 Downtown/Centre-ville].

Driven perhaps by similar motives, Egyptians take to Facebook and Twitter in the days leading up to the $25^{\text {th }}$ January, sharing their stories and pictures from five years back under the hashtag I participated_in_the_January_Revolution, which soon is among the most popular on social media. It is created in defence of the lawyer and human rights activist Taher Mokhtar (Țāhir Mukhtār), who is reportedly asked by a judge if he participated in "the violent events of 25 January 2011," after being detained by the authorities as part of their crack-down on political activism in the leadup to the anniversary [ 7 Social Media]. "Participating in the Revolution is not a crime," seems to be the initial motto of the campaign. Yet, while its message in support of the political detainees remains prominent throughout, the hashtag soon turns into an impromptu memorial wall of the revolution itself, with people sharing their personal experiences, stories, photos. "It was the best thing that has happened in the history of Egypt over the past 100 years," "The most noble thing I have ever participated in," "It is my present for my children and my grandchildren. I am sure that they will never give it up," "It's the greatest event my generation participated in," share Egyptians on social media, alongside pictures of current detainees, the people who lost their lives during the uprising and photos of the joys and sorrows of Tahrir square [ $\lambda$ Past $v s$. Present]. A perfect storm of nostalgia and defiance.

In response to the campaign, another hashtag is created, rather imaginatively named I- did not participate in the January_revolution, often used along with the emblematic Long_Live_Egypt or blessings of the souls of the policemen killed in the course of duty. ("Aha!," point out a few activists on Facebook, "so you do admit there was a revolution after all!"). A full-fledged Twitter war is now raging: on the one side the supporters of the revolution, defending its memory; on the other, the backers of the regime, expressing not

jais • 21 (2021) - Themed Section In2016: *45-*58 
only their support for the current government but also their rejection of the revolutionary ideals [ $\pi$ Clash]. Insults are flying on both sides, with people using both hashtags regardless of their views. It is a war of words and a battle over the legacy of the $25^{\text {th }}$ January, which many on social media believe is in danger of being "wiped out by the regime."

And indeed, they are not the only ones. "This wall is the last standing evidence [of the] revolution... if you go to Tahrir now, it is as if nothing happened," the Guardian quotes the writer Soraya Morayef (Thurayya Murāyif) referring to the systematic demolition of revolutionary graffiti and the "cleansing" of Downtown Cairo from all evidence that it was once the centre of mass anti-government demonstrations [ 7 Downtown/Centre-ville]. "It's like the revolution never happened," the sentence is repeated, this time by Kamal Mougheeth (Kamāl Mughīth) a researcher at Egypt's National Council for Education, commenting on the recent and last in a long line of changes to the school curriculum, leading to the removal of the name of al-Baradei (Muhammad al-Barādi' $\bar{i}^{1}$, an exiled Egyptian politician and outspoken supporter of the revolution) from the list of Egyptian Nobel laureates. It is an angry cry in defence of the few remaining tangible evidences that Tahrir happened, that it lives beyond the memory and the imagination of the street protesters and against the efforts to rewrite the country's recent history. For some, it is an attempt to recapture the feeling of the revolution, hoping that it would one day return: "I am alone," says Sanaa Seif (Sanā’ Sayf) embarking on her one-woman march to mark the fifth anniversary of the Revolution, "but I am sure that next year thousands will return to walk again from Mostafa Mahmoud to Tahrir Square." Yet, for others, it is a different story altogether. "We lost the battle over the future so now we fight to save the past," Omar Hamilton sums his experience up, "What else do we have left to fight with? That memory of possibility is all we have. Maybe, for now, it is enough." He depicts a gloomy picture of the past: irrevocably gone, remembered but also lost, the only standing ideal worth fighting for [ $\nearrow$ Past $v$ s. Present].

Who could imagine amidst this revolutionary blues that in a few short months the streets of Egypt would have once again caught the rebellious fever? The decision to transfer the two \Red Sea Islands of Tiran (Tīrān) and Sanafir (Șanāfirr) to Saudi Arabia sparks nationwide protests. On April 15, for the first time since al-Sisi assumed office, mass anti-government demonstrations take place. Larger protests are planned for the $25^{\text {th }}$, Sinai Liberation Day, marking the final withdrawal of the Israeli forces from the Sinai Peninsula - a public holiday that stands for Egypt's sovereignty and territorial cohesion. The popular hashtag Go out on the 25 April unites the opposition, with people denouncing not only the "sale of the land," but the social, economic and moral failures of the regime. The danger is sensed. After raging against "the hellish scheme" to destabilize Egypt from within, al-Sisi warns that "evil forces" are plotting against the country and expresses his belief that the honourable citizens "will not respond to calls for chaos" [ $\lambda$ The Honourable Citizen, $\lambda$ The Suspect Foreigner, $\lambda$ True vs. False]. Not that they are given much of an opportunity to do so, anyway. Mass arrests, dispersals and the overwhelming presence of the security forces in and around the big cities ensures that the people who gather to oppose the decision are not given the space to do so [ $\lambda$ Voice $\nu s$. Silence]. "The security forces are all over Cairo. It seems that al-Sisi is marking Sinai Liberation day by occupying the entire country," ironically comments Amr Abd alHadi ('Amr 'Abd al-Hādī) on Facebook.

jais 21 (2021) - Themed Section In2016: *45-*58 
Just blocks away from the original protest site, a very different celebration is taking place. Supporters of al-Sisi gather to mark the public holiday. Images and videos from the gathering soon go viral on social media. Loud music, raqș baladī performances [ $\lambda$ Pop Music], images of the President and chants of Long Live Egypt characterize the atmosphere in downtown Cairo. But the day is not to be spared the islands issue references. "If the Saudi king wants the pyramids or the Sphinx, he can have them," comments a fan of the president, waving a massive Saudi flag. One of several to be spotted at the location, much to the amusement of some of the social media commentators. "Well, they did say the islands were sold in the name of Arab unity. An Egyptian woman waving the Saudi flag on Tahrir Square during the celebration of Sinai Liberation Day: Isn't that the epitome of Arab unity?," points out one person. Another adds: "Four generations of honourable citizens! Tahyā masssssr!" (with the 'weak, effeminate' /s/ instead of 'strong, emphatic'/ș/), mocking the manner in which the President pronounces the name of the country in the emblematic "Long Live Egypt" slogan.

At the same time, a few kilometres down the road, a curtain is slowly being drawn back. An eerie figure appears on the balcony waving a hand to the small group of people gathered below. The action is set in the courtyard of al-Maadi Military Hospital and the man who has attracted the crowd is former president Hosni Mubarak (Husnī Mubārak). Days before his birthday, supporters of the ousted leader gather to mark Sinai Liberation Day, the greatest achievement of the former regime, according to its proponents. But also, much more than that. It is a statement against the recent political developments in Egypt, starting from the January revolution on. It is perhaps as much a call to remember as it is an invitation to forget [ $\lambda$ Past vs. Present].

The holiday turns into a battlefield of the past, the present and the future, generating numerous responses to what ought to be happening in Egypt, yet little dialogue. One Facebook comment sums up the event:

The day is altogether strange! Supporters of al-Sisi dancing to celebrate Sinai Liberation Day. Supporters of Mubarak in front of the hospital ... Youths like roses being arrested for protesting the sale of the land. And those in power looking from afar. It's madness, gentlemen, madness.

June 30. It is almost the end of Ramadan. The day is hot and sunny, with temperatures topping out in the thirties. Egypt is settled into the half-awake routine which accompanies the fast, especially in the summer. But today is different. Early in the morning military jets are roaring over Cairo. Al-Sisi's face is beaming from the screens, as he congratulates the nation in a pre-recorded address. The air is thick with anticipation. As the sun goes down over Egypt, people begin to appear after their late nap. Crowds are slowly filling the streets. This time the joys of the 'iftatr are multiplied. Across public squares, schools and stadiums, official figures, citizens, poets and artists are gathering to enjoy an evening of entertainment. The scenes are changing rapidly: a folklore ensemble playing flutes and drums, a poet reciting a few uplifting patriotic verses, a politician giving an optimistic speech, students wrestling. The Egyptian flag is proudly displayed on stages, cars, windows, shops and food carts. Fireworks light the skies over towns and cities. Egypt is celebrating for the first time the third anniversary of the protests against former president Mohamed Morsi (Muhammad Mursī) as an official holiday. 
But three years on, the legacy of the event is still a hot topic. The focus of the discourse is being shifted towards the protests of the end of June and the July overthrow of the Morsi regime is rarely mentioned. "The Egyptian people reclaimed their identity during the June Revolution," argues al-Sisi in his speech commemorating the anniversary of the protests. The tone is mimicked by al-Mașrī al-Yawm:

Three years ago a milestone in the history of Egypt was achieved by the millions of people who went out on the street and demanded: give us our country back. They said no to the cheap attempts to divide the Egyptian society and to control the state with repression and terrorism.

Yet others are more careful with their descriptions. MadàMașr (Madà Mașr), for example, invites participants in the June 30 "movement" to discuss the situation in the country then and now. A mistake, the only way out, what was perceived as the right course of action at the time, a trick. These are just some of the ways in which the (mostly) young activists describe the protest. On one thing, however, they agree: "Right now, it is we who have been ousted... Anything that the Brotherhood would have done, the current state is doing. The religious and military regimes are two faces of the same coin" [ $\nearrow$ Present $=$ Past (Stuck)]. Similar argument is echoed by Amin Iskander ('Amīn 'Iskandar), the founder of the Karama (Karāma) party in an article published by al-Badīl: "By all accounts the $30^{\text {th }}$ of June was a real revolution, but it failed to empower young people. Just like the January Revolution was hijacked by the Brotherhood, the June Revolution was overtaken by the military."

The debate is not confined to mainstream media. Thus, while many are busy celebrating the revolution by posting glorifying pictures of al-Sisi on Facebook and Twitter, others are attempting to deal with the legacy of the events and the choices they had made. "Was the $30^{\text {th }}$ June a revolution? It was the only possible course of action regardless of what you call it. Do I regret participating? Of course not. It saved us from the dictatorship of political Islam," posts one person. "The $30^{\text {th }}$ June was a counter-revolution. The $3^{\text {rd }}$ July was a coup," adds another. "What happened between the $3^{\text {rd }}$ and the $7^{\text {th }}$ was a full-fledged military coup," writes a Facebook user, four raised fingers decorating his cover photo, "[which the army achieved by] taking advantage of the popularity of the June $30^{\text {th }}$ demonstrations." It is not surprising, then, that a question posed by the Facebook page Khawātir sināwiyya attracts more than 100 comments. A coup or a revolution? The opinions are polarized. While there are more people who perceive it as a coup rather than a revolution, the overwhelming majority is somewhere in the middle. "Both," "neither," "half and half," "thawqalāb." Yet for others it matters little. "It is just a public holiday," take it or leave it.

The coup vs. revolution question also casts its shadow on another memorial day. "The commemoration of the $64^{\text {th }}$ anniversary of the July coup in Egypt comes amidst many complex issues in the regional and international arena." Only a week ago the Turkish military attempted a coup against president Erdogan and there are many similarities between this and what happened on the $23^{\text {rd }}$ July 1952 . Thus begins a report published by al-Taqrīr. The article goes on to outline the parallels and differences between the two events. But the final sentence is particularly illuminating. "What is this revolution they speak about? If there ever was one, it failed to achieve its goals. [The $23^{\text {rd }} \mathrm{July}$ ] is a coup in which the army forces assume power and replace the old leaders with their own men. That is all, nothing else." It goes to the core

jais 21 (2021) - Themed Section In2016:*45-*58 
of an old debate, rekindled perhaps even more by the events in Turkey. Yet another page in Egypt's history book that is being constantly rewritten.

"Nothing is neutral and objective, unless we call things by their real names. The $23^{\text {rd }}$ July is a coup. The $25^{\text {th }}$ January is a revolution. The $3^{\text {rd }}$ July is a coup," writes Ayman Nour ('Ayman Nūr) on Twitter. But Ahmed Moussa disagrees. "The 23 $3^{\text {rd }}$ July was a revolution, undertaken by the army and supported by the people. As for the $30^{\text {th }}$ June, it was a revolution undertaken by the people and supported by the army." Or maybe the truth is somewhere in the middle. "A coup turned revolution," as Alaa al-Aswany ('Alä' al-'Aswānī) prefers to call it.

Yet, why does it matter 64 years later? Regardless of their opinions, the one thing most commentators agree on is that the July 1952 events profoundly changed Egypt and its people, as a heated discussion on the Official Page of King Faruq suggests. Whether it is "the source of all evil" and "the reason for all of Egypt's current problems" or what saved the people from "poverty and ignorance," there are few who do not link the Free Officers' movement to the fabrics of the modern state. Jihan al-Tahri's (Jihān al-Ṭāhirī) Egypt's Modern Pharaohs makes a similar point. The historical documentary looks back at the political developments in the country since 1952. Based on interviews, videos and other primary sources, the work tells the stories of three Egyptian presidents: Nasser, Sadat and Mubarak. While different in terms of their personalities and policies, the three have one notable thing in common: they are all heirs and representatives of the political and social system that was created with the July events. The beginning of the never-ending era of the "pharaohs" in Egypt [ $\neg$ Father Figures].

Is it surprising then that the date is also used to understand and qualify the recent developments in Egypt? "We are convinced that the $30^{\text {th }}$ June popular revolution against the injustice and the tyranny of the Muslim Brotherhood gangs is the guardian of the principles of the July $23^{\text {rd }}$ revolution," writes Mustafa Hamdan (Muștafà Hamdān), the leader of the Movement of the Independent Nasserites in a letter sent to al-Sisi in commemoration of the $23^{\text {rd }}$ July. "We are always going to stand behind an Egypt which leads our Arab nation in the quest to restore stability, dignity and security." The two "revolutions" are seen as two chapters of the same story, the uninterrupted historical narrative of Egypt.

Is January 25 a revolution against the state of July or is it its legitimate daughter?, asks Ayman al-Sayyad (Ayman al-Șayyād) from his corner. The hysteria and schizophrenia which characterizes the polarization in Egypt and which are strengthened by the recent developments in Turkey are not likely to give any answers. But it should be remembered that the 1952 revolution had set ambitious goals for the development of Egypt. What is more, continues the author, it had changed society as a whole, providing Egyptians with ideals to inspire to. All the demonstrations from the 1970s and 1980s are linked to this change, they were aimed at correcting the course of the revolution and so was the January uprising. "The January Revolution came to save the $23^{\text {rd }}$ July, which was lost or almost lost," it came to complete the project that had started 51 years ago. And this is the soundest evidence of the importance of the July revolution. It represents the "irreplaceable necessity for a promising future." And this is worth remembering, concludes al-Ṣayyād.

"I am proud. First, it is the culmination of a very long career. On Independence Day, I was here," notes Tunisian president Essebsi on the anniversary of the independence of 
Tunisia from France, "I'm thrilled to celebrate this 60th anniversary, and congratulate my people." In one sentence, he manages to both state the importance of the event and portray himself as an essential part of it. The President talks about the achievements of Habib Bourguiba (Habīb Būrqība) and vows to protect his legacy and that of other prominent figures, most notably by moving the statues of Bourguiba back to Tunis. In the spirit of any political speech ever written, Essebsi also reflects on the challenges of the present: terrorism, the economic and social situation, the marginalization of "certain regions." National unity is needed to deal with these major issues and any contrary action "may affect the country's interest," warns the president in lieu of conclusion. The speech is ordinary in many ways, apart from the Essebsi's evident desire to show himself not only as an admirer but as continuation of the post-colonial regime.

An analysis published by Histoire et culture dans la Tunisie contemporaine may explain why. Bearing the title Bourguiba: always present, always current, the article dissects the layers of the former leader's complicated legacy. For the authors, the powerful image of Tunisia's "Supreme Combatant" still stands as a synonym of modernization, progress, independence, as an embodiment of the true identity of Tunisia. And this explains why politicians from all sides of the spectrum are referring to him in their speeches. It is a way not only to use his popularity to progress their agendas, but also means to hide the "absence of their own political vision" [ $\lambda$ Father Figures].

In the height of summer, another anniversary is quietly taking place in Egypt:

That day, every half an hour, a friend of mine was killed. The news came quicker than I could process. I walked through the roads, roads heavy with smoke, blood and burnt black. All the tents, the people, the shops, the food, everything, everything was burnt, the world had turned to ashes.

This is how those who were at Rabaa al-Adawiya (Rābica al-'Adawiyya), the square where hundreds of Muslim Brotherhood supporters were killed in a single day three years ago, remember the events. For them, it is a story of horror and anger and despair. "I resent myself for not calling Habiba and hearing her voice," a young girl exclaims, "I resent those who made this possible. I resent the person who pulled the trigger. I resent those who gloated as my sister was dying." The pain of knowing what happened is only matched by the thought that you may never find out. "He went, and never came back. We never found his body, we never found his name in any detention facility, it's almost like he never existed," recalls the grieving mother of a disappeared son, "I miss him so much, and I feel so helpless" [ $\nearrow$ Disappearances]. It is a day that none of those who were there will be able to forget any time soon: "You can't unsee some things," says a field doctor who was taking care of the injured on the August 14, "you could never forget the stench of charred skin that steeped in and clung to you for days and at times, feels like it never left."

But even those who were nowhere near are still haunted by the memories: "I wasn't there, but I saw the footage. I saw a young girl weeping on her brother's chest, witnessing his last breath," writes Salma Essam (Salmà 'Ișām),

I wasn't there, but I saw the rows of corpses laid out in white coffins, awaiting collection by relatives, in a Cairo mosque. I was there watching members of the media

jais 21 (2021) - Themed Section In2016: *45-*58 
blessing these acts of murder. I was there when the murdered were called 'terrorists' and the murderers became the 'saviors'.

Stories of trauma, loss and grief are told in foreign outlets, marking the anniversary. But the legacy of Rabaa seems to spread beyond the day itself in Egypt. "The anniversary of the massacre is not a Karbalai event where we weep every year, but we commemorate every day, by working hard to foil the coup," reads a general statement, released by the Muslim Brotherhood on August 14. "We were and we will continue doing so peacefully."

The official narrative, however, tends not to see things this way. On the anniversary of Rabaa, Youm 7 releases for the first time information from the official public prosecutor's report on the case and it tells a very different story, the one maintained by the authorities for three years now. Following the June revolution, supporters of the ousted leader of the Muslim Brotherhood had occupied the Rabaa square, organizing "an armed sit-in." The protesters had not only closed the roads around the square but had harassed the people living in the area. They had prevented them from leaving their apartments and going to work, violently responding to any attempt to pass by the sit-in. The MB supporters had even seized the nearby mosque and hospital, setting up rooms for detention and torture, the report goes on. Responding to complaints by locals, the security forces had tried to disperse the crowds, but the protesters have thrown stones and Molotov cocktails and had used firearms, leaving one policeman dead. After exhausting all peaceful methods, both locally and internationally, of persuading the people to leave, the security forces had begun to clear up the square. The protesters, however, had once again responded with violence, injuring policemen. The state apparatus had had no choice but to adopt equal measures, resulting in "some injuries and casualties" among those gathered at Rabaa. It is clear, the article concludes, that it was the organizers of the protest that are to blame for the violence that took place, even though now they are using the events to portray themselves as victims. The armed forces of the state? They were just doing their job [ $\neg$ Security $\nu s$. Fear]

But there is another group of people who look back at Rabaa often, as a conversation among representatives of Egypt's pro-democratic forces, recoded by MadàMașr, shows. "Wasn't there a fascist sentiment that actually wanted to close public space [among those who took to the streets on June 30]?," asks Nael al-Toukhy (Nā’il al-Ṭūkhī). "That does not mean that people wanted to slaughter the Brotherhood. If 100 were slaughtered instead of 1,000 , nobody would have been upset. And, if no one was slaughtered, even better," comes Amr Abdel Rahman's ('Amr 'Abd al-Raḥmān) answer. Elham Eidaros ('Ilhām 'Aydārūs) disagrees. According to him, people's mood for blood was building up in light of the panic from repeated sexual and sectarian attacks. "The Islamic current bears the responsibility for preparing the masses for higher levels of oppression," argues the activist, bringing elements of the official discourse. All the Brotherhood arrests and even the Rabaa sit-in dispersal were celebrated until very late, adds to the confusion Belal Alaa (Bilāl 'Alä'). The opposition of the democratic forces to "the violent public sentiment" is "coming too late." Justifying, shifting the blame, taking responsibility: just some of the ways in which the participants in the June movement are trying to deal with the implications and memory of their past decisions.

How can a massacre be justified, celebrated, erased from history? These are the questions raised by a MadàMașr article. The Rabaa massacre, like any mass killing, begins the author,

jais • 21 (2021) - Themed Section In2016: *45_*58 
happened because the perpetrators succeeded in depriving their victims of the right to exist. Its biggest tragedy is not the loss of life but the loss of consciousness. The slaughtered MB supporters ceased to be part of Egypt. They became "an "other," an opposing "other," an "other" that we perceive as different and it perceives us as different, an "other" who we can dress in the devil's mask, incite hatred against as an enemy, and erase from existence." And this is what paved the way to "cheap murder, accompanied with jubilation and cheering for victory" [ $\nearrow$ True vs. False]. Even those from the civilian camp who acknowledge the victims do not see them as their martyrs, but those of the "other." They are merely pitied because all is ill-gotten. Rabaa, thus, is not a tragedy only of the Brotherhood, but of the Revolution as a whole, because the legitimization of the massacre solidifies the discourse of the counterrevolution. It changes the battle from one based on political and social issues to one based on identity. And it turns into something that cannot be won, until one truth is accepted: There are no devils among us, just people with power and those who they deprive of "bread, freedom and social justice," concludes the piece.

\section{Related Entries}

ARRAYs - Clash $\downarrow$ Disappearances $\downarrow$ Downtown/Centre-ville $\downarrow$ Father Figures $\downarrow$ The Honourable Citizen $\downarrow$ Mobile Phones Pop Music $\downarrow$ Red Sea Islands $\downarrow$ Social Media $\downarrow$ The Suspect Foreigner $\downarrow$ Tourist Resorts Tricking the System / Tricked by the System $\downarrow$ The Voice from Above.

CODES - Freedom $v s$. Constraint $\downarrow$ Hope $v s$. Hell $\downarrow$ Inferiority $v s$. Superiority $\downarrow$ Normality $v s$. Heroism $\downarrow$ Past vs. Present Security vs. Fear True vs. False Voice vs. Silence.

Codes ColLAPSED - Inferiority $=$ Superiority $($ Satire $) \diamond$ Present $=$ Past $($ Stuck $)$

\section{References}

\section{Written}

“30 yūniyū...Thawrat al-sha'b al-makhțūfa." Al-Badīl, July 1, 2016, <https://bit.ly/2srQESX>.

"Activist Stages Single-Person Demonstration in Tahrir Square." Ahram Online, January 25, 2016, $<$ http://english.ahram.org.eg/NewsContent/1/64/185905/Egypt/Politics-/Activist-stagessingleperson-demonstraction-in-Tahr.aspx $>$.

“'Asrār 'Faḍḍ Rābi'a' min 'arshīf al-Niyāba [...]." Youm7, August 14, 2016, <https://bit.ly/2LcBvvJ>.

“Ayman Nūr: 23 Yūliyū 'inqalāb', wa-'Aḥmad Mūsā: al-Jaysh al-mișrī qāma bi- 'thawra'.” CNN Arabic, July 24, 2016, <https://arabic.cnn.com/middleeast/2016/07/24/egypt-23-july-1952-anniversary>.

"Bada’a l-iḥtifâl bi-'̄̄d al-Shurța." Youm7, January 23, 2016, <https://bit.ly/2LJiQsi>.

BEN FrAJ, Rim. “À Peine j’ouvre les yeux : Un film contre l'amnésie et la nostalgie.” Nawaat, March 29, 2016, <https://nawaat.org/portail/2016/03/29/a-peine-jouvre-les-yeux-un-film-contre-lamnesie-et-lanostalgie/>.

Ben HMidA, Cheima. "Five Years On, Tunisians Share Memories From The Jasmine Revolution." Huffington Post, January 15, 2016, <https://www.huffingtonpost.com/entry/jasmine-revolutiontunisia-anniversary_us_56993211e4b0b4eb759e367c?guccounter=1>.

"Bi'l-fĩdiyū: Al-Sīsī yașilu 'Akādīmiyyat al-Shurța.” Youm7, January 23, 2016, <https://bit.ly/ 2xuftT5>.

"Bi'l-fīdiyū wa-șuwar... 5 Mushāhid fì 1-iḥtifāl bi-'Īd al-Shurța." Youm7, January 23, 2016, <https:// bit.ly/2snFA9d>.

jais 21 (2021) - Themed Section In2016:*45-*58 
"Bi'l-fîdiyū wa-șuwar... Nașṣ kalimat al-Ra'īs al-Sīsī fì l-iḥtifāl bi-'̄̄d al-Shurța." Youm7, January 23, 2016, <https://bit.ly/2Jn2oQ1>.

"Bi'l-fìdiyū... Mu’ayyidū al-Sīsī: Law malik al-Sacūdiyya țalaba al-’ahrāmāt 'ha-niddīhā-luh." Rassd, April 25, 2016, <http://rassd.com/184601.htm>.

"Bourguiba: Always Present, Always Current." Histoire et Culture Dans La Tunisie Contemporaine, April 7, 2016, <https://hctc.hypotheses.org/1501>.

Dettmer, Jamie. “Anti-Government Protesters Threaten to Defy Egyptian President.” Voa News, April 24, 2016, <https://www.voanews.com/a/anti-government-protesters-threaten-to-defy-egyptianpresident/3300395.html>.

"Egypt: The Mainstream Media Has Forgotten about the 'orphan Revolution." Al-Akhbar Lebanon, January 25, 2016, <https://mideastwire.com/page/articleFree.php?id=59592>.

"Egyptian People Reclaimed Identity in 30 June Revolution: Sisi." Ahram Online, June 30, 2016, $<$ http://english.ahram.org.eg/NewsContent/1/64/232208/Egypt/Politics-/Egyptian-peoplereclaimed-identity-in--June-revolu.aspx $>$.

“Egypt's Military Deploys to Secure 'Sinai Day Celebrations' Ahead of Planned Protest." Egyptian Streets, April 24, 2016, <https://egyptianstreets.com/2016/04/24/egypts-military-deploys-tosecure-sinai-day-celebrations-ahead-of-planned-protests/>.

“"Erase and I Will Draw Again': The Struggle behind Cairo's Revolutionary Graffiti Wall.” The Guardian, March 23, 2016, <https:/www.theguardian.com/cities/2016/mar/23/struggle-cairo-egyptrevolutionary-graffiti>.

EsSAM, Salma ('IȘĀM, Salmà). "Cairo's Rabaa Massacre: Three Years On, the Smell of Death Still Lingers." Global Voices, August 14, 2016, <https:/globalvoices.org/2016/08/14/cairos-rabaamassacre-three-years-on-the-smell-of-death-still-lingers/>.

"Facebook Post." The Official Page of King Faruq, February 18, 2016, <https://www.facebook.com/ king.farouk.faroukmisr/photos/a.116859731748670.14224.102433933191250/819382818163021/ ?type $=3 \&$ theater $>$.

“Facebook Post." April 24, 2016, <https://www.facebook.com/amrabdelhadypolitician/posts/ $1332672896747152>$.

“Facebook Post." June 18, 2016, <https://www.facebook.com/alhaitham.saad/posts/ 1249490181736470>.

"Facebook Post." Khawāțir Sināwiyya, July 1, 2016, <https://www.facebook.com/permalink.php? story_fbid=1029368543826542\&id=505737276189674>.

"Facebook Post." July 1，2016, <https://www.facebook.com/ayman.taha1/posts/ 10153463387837723>.

“Facebook Post." July 16, 2016, <https://www.facebook.com/hatem.saber1/posts/ 10154109015747745>.

“Facebook Post." November 28, 2016, <https://www.facebook.com/hosameldeen4/posts/ 10208934894742759>.

"Facebook Post and Comments." April 25, 2016, <https:/www.facebook.com/Thawrah2Day/videos/ $10154955914928561 />$.

GomaA, Ahmad, and XINHUA. Former Egyptian President Hosni Mubarak Waves to His Supporters as They Gather in Front of Maadi Military Hospital Where Mubarak Is House Arrested in Cairo, Egypt on April 25, 2016. April 25, 2016, Photography. <http:/www.xinhuanet.com/english/ photo/201604/26/c 135311395 8.htm>.

jais • 21 (2021) - Themed Section In2016: *45-*58 
Hamilton, Omar. "The Memory of the Egyptian Revolution Is the Only Weapon We Have Left." The Guardian, January 25, 2016, <https://www.theguardian.com/world/2016/jan/25/egypt-revolutionfive-years-omar-robert-hamilton>.

Hashtag "Anā_mashāraktish_fī_thawrat_yanāyir.” Twitter, n.d. $<$ https://bit.ly/2stz7J5>.

Hashtag "Anā_shārakt_fī_thawrat_yanāyir.” Twitter, n.d. $<$ https://bit.ly/2skW6XE $>$.

Hashtag “'Inzil25abril.” Facebook, n.d. $<$ https://bit.ly/2st6CLv>.

Hendawi, Hamza. "Satirical Video of Egyptians Giving Police Condom Balloons Could Land Filmmakers in Jail." The Independent, January 27, 2016, <https://www.independent.co.uk/news/ world/africa/satirical-video-of-egyptians-giving-police-condom-balloons-could-land-filmmakersin-jail-a6836071.html>.

“'I Still Cry Every Time I Hear Her Name': Rabaa Families Struggle to Move On.” Middle East Eye, August 14, 2016, <http://www.middleeasteye.net/in-depth/features/i-still-cry-every-time-i-hearher-name-rabaa-families-struggle-move-1506359502>.

“June 30, 3 Years on: Protesting Intellectuals Revisit Their Position.” MadàMașr, July 1, 2016, <https:// www.madamasr.com/en/2016/07/01/feature/culture/june-30-3-years-on-protesting-intellectualsrevisit-their-position/>.

“Li-mādhā najaha inqalāb 1952 ḍidd al-malik Fārūq wa-fashala ḍidd 'Ardūghān fĩ 2016?" Nūn Būst, July 23, 2016, <https://www.noonpost.org/content/12990>.

“al-Mașrī al-Yawm tarșudu najāhāât wa-'ikhfāqāt Thawrat 30 Yūniyū.” Al-Masry Al-Youm, July 2, 2016, $<$ http://www.almasryalyoum.com/news/details/973693>.

"Muhāfaẓāt Miṣr tashtacilu iḥtifālan bi-dhikrà 30 Yūniyū." Youm7, July 1, 2016, <https://bit.ly/ $2 \mathrm{kE} 6 \mathrm{LZi}>$.

“al-Nāṣiriyyūn al-Murābiṭūn tuhanni’ al-Sīsī bi-munāsabat dhikrà Thawrat Yūliyū.” Al-'Usbūc, July 22, 2016.

"Nașṣ kalimat wazīr al-dākhiliyya fī ḥafl 'Īd al-Shurța al-64.” Youm7, January 23, 2016, <https://bit ly/2J008z5>.

"Questions about June 30: Who Were We and What Were We Thinking? Part 2." MadàMașr, July 10, 2016, <https://www.madamasr.com/en/2016/07/10/feature/politics/questions-about-june-30-whowere-we-and-what-were-we-thinking-part-2/>.

Raghavan, Sudarsan. "In New Egyptian Textbooks, 'It's like the Revolution Didn't Happen." The Washington Post, April 23, 2016, < https://www.washingtonpost.com/world/middle east/in-newegyptian-textbooks-its-like-the-revolution-didnt-happen/2016/04/23/846ab2f0-f82e-11e5-958dd038dac6e718 story.html?noredirect $=$ on\&utm_term $=.7 \mathrm{dba9} 91 \mathrm{flb} 573>$.

“Révolution?” DEBATunisie (blog), January 14, 2016, <http://www.debatunisie.com/archives/2016/ 01/14/33208125.html>.

ȘAYYĀD, ’Ayman al-. "23 yūliyū - 25 yanāyir: al-Su’āl al-qadīm al-jadīid.” Al-Shurūq, July 24, 2016, $<\mathrm{http}$ ://www.shorouknews.com/columns/view.aspx?cdate=24072016\&id=2a694f49-c00e-4281$85 \mathrm{e} 8-981 \mathrm{f} 6 \mathrm{~b} 560 \mathrm{e} 2 \mathrm{~b}>$.

"Sisi: Internal Plots to Destroy Egypt Worry Me More than External Threats." Ahram Online, April 15, 2016, <http://english.ahram.org.eg/News/199646.aspx?mc_cid=29789220e0\&mc_eid=4dfd03646c >.

SzAKAL, Vanessa. "In Tunis, Demonstrators Are Still Chanting the Slogans of the Revolution." Nawaat, January 17, 2016, <https://nawaat.org/portail/2016/01/17/in-tunis-demonstrators-are-still-chantingthe-slogans-of-the-revolution/>.

“al-Ṭifl Haytham Muḥammad yulqī qașīdat 'al-Shahīd.”' Youm7, January 23, 2016, <https://bit.ly/ 2L9WhMk>.

jais 21 (2021) - Themed Section In2016:*45-*58 
"Tunisia: 60 Years of Independence, the Past." Tunisia-Tn.Com, March 20, 2016, <http://tunisiatn.com/tunisia-60-years-of-independence-the-past/>.

“Tunisia: 60 Years of Independence, the Present Challenges." Tunisia-Tn.Com, March 20, 2016, $<$ http:/tunisia-tn.com/tunisia-60-years-of-independence-the-present-challenges/>.

“Tunisians Mark Fifth Anniversary of Revolution.” Al-Bawaba, January 15, 2016, <https://www. albawaba.com/news/tunisians-mark-fifth-anniversary-revolution-793384>.

WAGuin, Tamer. "Cairo, Massacres and Our History." MadàMașr, September 1, 2016, <https://www. madamasr.com/en/2016/09/01/opinion/politics/cairo-massacres-and-our-history/>.

"Willis fête ses 5 ans! (Facebook Post)." Willis in Tunis, January 13, 2016, <https://www.facebook com/145189922203845/photos/a.145209278868576.27277.145189922203845/996826207040208 /?type $=1 \&$ theater $>$.

Youssef, Adham. "Brotherhood Vows to Remain 'Peaceful', Calls for Unity on Third Rabaa Anniversary." Daily News Egypt, August 15, 2016, <https://dailynewsegypt.com/2016/08/15/ brotherhood-vows-remain-peaceful-calls-unity-third-rabaa-anniversary/>.

\section{Films}

Egypt's Modern Pharaohs. Documentary trilogy by J̄̄hān al-Ṭāhirī (Jihan El-Tahri). Egypt, France, USA, Qatar 2015/2016. 